\title{
HOW DOES TRANSNATIONAL ISLAMIST TERRORISM CHALLENGE THE CONCEPTIONS OF (INTER)NATIONAL SECURITY?
}

GIADA GAROFALO

\section{ABSTRACT}

This article questions the meanings of international and national security analysing a current security issue, Islamist terrorism, through a critical approach to two mainstream conceptions, the narrow territoria one of neorealist tradition and the idea of extended security derived from globalist perspectives of which the final referent object is no longer the State but the individual.

Drawing on Regional Security Complex Theory to bridge the opposition between the two and to highlight the interconnectedness of different levels of analysis (national, regional, global) this article finally suggests that the security threat posed by Islamist neofundamentalism as ideology behind terrorism could also be read in terms of the construction of a transnational identity in opposition to one of the State's traditional sources of identity, the nation. Being, in fact, this new identity founded on the value of universalism, it is transnational not only territorially but also because it opposes a national dimension both culturally and politically.

Consequently, such opposition can be understood as an issue of national security - especially in multi-national states in which however one nation is dominant over the others within the territory - as it competes with, offers itself as alternative to one of the three elements that form the State, its identity which is the bonding agent between its governing institutions and its physical base; and has also repercussions in terms of international security because in an international system formed predominantly by states, it questions the idea of the (modern) state rather than just its incapacity to deal with international problems.

\section{KEYWORDS}

Security, Terrorism, Political Islam, Globalisation, Identity 


\section{Introduction}

The irony about security studies is that in spite of the importance of such concept, a commonly accepted definition of what security means is still missing. This even though it lies at the foundation of the modern state: what was the social contract, and the loss of freedoms that it involved, if not a way to exit the state of nature, highly insecure environment for the individual? Nonetheless, the difficulty of finding an agreement in the literature is justified by the fact that firstly it is not possible to objectively define what sources of potential threat should be securitised; and then that the disputes on whether security has to be intended in military, rather than economic or environmental terms, regard only one aspect of security, which is, in fact, a bi-dimensional concept as "...in an objective sense, [it] measures the absence of threats to acquired values, in a subjective sense, the absence of fear that such values will be attacked."'

Indeed, during the years of the Cold War was prominent the neorealist position which looks at security from a militaristic angle, as territorial national security within a state-centric international arena regulated by the principle of sovereignty. However, during the 1980s and especially after the end of the bipolar opposition, new studies emerged which started to consider other aspects of (in)security within a more interconnected international system, where in parallel with the security of the state, exclusive actor in the neorealist perspective, security issues were considered at the individual level, as human security, and linked to discussions on modernity/globalisation, global governance and the emerging role of transnational non-state actors.

My argument, instead, is that global Islamist terrorism, of the type experienced in the last decade and especially since $9 / 11$, enters the debate on international security challenging both these two main currents of thought. First, in terms of international security, being it the result of a complex intersection of local, national and global elements and using a political-religious discourse, it cannot be

${ }^{1}$ Arnold Wolfers, "National Security, as an Ambiguous Symbol," Political Science Quarterly 67(4) 1952, p.485. (Emphasis added.) 
2006] HOW DOES TRANSNATIONAL ISLAMIST TERRORISM

understood merely at the system level analysis as argued by neorealists; i.e. the analysis of the anarchic structure in which is central the national level, represented by state-units playing the geopolitical and military power-game within the international arena. At the same time, however, at the other end of the spectrum it also challenges the globalist positions, with which I label those theories (Booth, Rotschild, Held, etc.) that take into account - either in liberal (favourably) or non-liberal (critical) way - the phenomenon of globalisation and look at security issues from this angle. These perspectives lie at the opposite end of the spectrum because neorealists, on the other hand, deny the importance or novelty of such phenomenon, which for example in terms of economic globalisation intended as continuous growth of trade and investment - has already manifested in three major phases since $1870 .^{2}$ Specifically, globalist positions have the advantage of widening the international security agenda against the narrower neorealist perspective. Yet, they present a concept of security which is too wide. Moreover, in terms of governance they shift the focus from the national level to the relation between the individual and global levels - individual and global security - thus overlooking the still important role of the state, and falling in the contradiction of wanting to dismiss the state in favour of international organisations but at the same time of strengthening its traditional idea transposing to the international level "universal" values, like democracy, representation, transparency, liability etcetera, which are contingent to the historical development of the modern state in Europe. As argued in this essay, instead, an analysis of Islamist terrorism cannot be carried on without considering the national level not only in relation to an investigation of its causes but also for the fact that in terms of national security the threat of global Islamist terrorism is directed against the idea of state.

The second challenge of terrorism, in fact, regards the conception of national security. My position is that, among more evident reasons, it becomes a national security issue because it appeals to the idea of a transnational identity, where transnational is not intended in spatial-territorial terms, across nations, but is understood in the figurative meaning that the prefix trans has in Latin, suggesting something which goes over a determinate

2Paul Hirst, "The Global Economy-Myths and Reality," International Affairs 73 (3), 1997, s. 410-411. 
form/dimension. Specifically, if we intend the state as a combination of three elements, territory/population, institution and idea of the state, which is based on nation and organising ideologies as sources of identity of the state, ${ }^{3}$ the fact that Islamist neofundamentalism, of which terrorism is the violent expression, is trying to construct a universal identity, which is based on the principles of deculturation and deterritorialisation and which is not linked to the objective of establishing any kind of state, is a direct threat to the security of the state, and in relation to the state needs to be analysed and dealt with.

To develop my argument, I shall draw on the Regional Security Complex Theory ${ }^{4}$ which I believe is better equipped to highlight the dynamics between local, national and global levels and on Buzan's definition of the state just presented, which I use to read the relation between Islamist transnational identity and state identity in terms of national security.

The choice to focus my work on global Islamist terrorism derives mainly from two considerations: in a first instance the evident fact that the indiscriminate violence of terrorist attacks is a matter of security, and of international security for the way they are organised and perpetrated across different countries. Secondly, because I think that more than any other "global" issues (being these environment, migration or drug trade) it offers the chance to really question the idea of the state, not just transposing its principle to the international level.

To develop my argument, I shall proceed dividing this paper in three sections. The first is more descriptive and serves to contextualise the debate on international security presenting the three approaches above mentioned more in detail: neorealist ${ }^{5}$, globalist $^{6}$

${ }^{3}$ Barry Buzan, People. States and Fear, Hemel Hemstead: Harverster Wheatsheaf, 1991

${ }^{4}$ Barry Buzan and Ole Waever, Regions and Powers, The Structure of International Security, Cambridge: Cambridge University Press, 2003.

5John Mearsheimer, "The False Promise of International Institutions" International Security 19(3) 1994-95, pp. 5-49; Kenneth Waltz, "The Emerging Structure of International Politics" International Security 18(2) 1993, pp.47-79; Kenneth Waltz, "Globalization and Governance" PS: Political Science and Politics 32(4) 1999, pp. 693-700. 
2006] HOW DOES TRANSNATIONAL ISLAMIST TERRORISM

and Security Complex Theory. The second looks at the relation between Islamist terrorism and international security through an analysis of the historical development of Islamism and of its tridimensional character, contingent in its origins, ${ }^{7}$ transnational in its organisation $^{8}$ and global in its theoretical foundation and unintentional effects. ${ }^{9}$ Finally, the third part is dedicated to the relation between neofundamentalism and national security for what concern the threat deriving from the construction of a transnational identity embodied by a universal imagined community, the ummah. ${ }^{10}$

\section{The debate on International Security}

In this section I introduce the main theories on international security, which will serve as background to my argument. To generalise and give them a temporal sequence, it can be said that the neorealist theory dominated in the 1970s throughout the Cold War years, in what Walt calls the "renaissance of security studies." 1 Globalist perspectives, instead, started to assume more weigh in the 1980 s and especially in the 1990 s, in parallel with the debate on globalisation, looking at referent objects of security other than states,

${ }^{6}$ Ken Booth, "Security and Emancipation" Review of International Studies 17(4) 1991, pp. 313-326; David Held, "Democracy and the New International Order", Archibugi D. and Held D. (eds.) Cosmopolitan Democracy, Cambridge: Polity Press, 1995, pp. 96-120; E. Rothschild, "What is Security?" Daedalus 124 (3) 1995, pp. 53-98

${ }^{7}$ Fred Halliday, Two Hours that Shook the World: September $11^{\text {th }}$ and its Consequences, London: Saqui, 2002; Fred Halliday, The Middle East in International Relations, New York: Cambridge University Press, $2005 \mathrm{pp}$ 229-260; Fred Halliday, Islam and the Myth of Confrontation, London: I.B. Tauris \& Co., 2003.

${ }^{8}$ R. Crockatt, America Embattled: September 11, Anti-Americanism and the Global Order, London and New York: Routledge, 2003: M. Mahmood, Good Muslim, Bad Muslim: America, the Cold War and the Roots of Terror, New York: Three Leaves Press, 2005; A. Rashid, Taliban: the Story of the Afghan Warlords, London: Pan Books, 2001

${ }^{9} \mathrm{~F}$. Devji, Landscapes of the Jihad, London: C. Hurst \& Co., 2005.

${ }^{10}$ Oliver Roy, Globalised Islam, The Search for a New Ummah, London: C. Hurst \& Co., 2004.

${ }^{11}$ S. M. Walt, "The Renaissance of Security Studies," International Studies Quarterly 35(2) 1991, p. 211 
either at the individual or global level. Finally a third school of thought Regional Security Complex Theory, which has developed as well since the 1980s, positions itself in the middle of the spectrum, trying to highlight any interconnections between levels (individual, regional, system) and five security sectors (military, political, environmental, societal, economic).

\section{Security as territorial security: a neorealist perspective}

Although the neorealist position does not present itself in a homogeneous way - in fact, several variations have emerged during the years - some common features can be identified. In primis, the security problem for the neorealist is given by the anarchic structure of the international system and by the fundamental lack of trust among states. In this case, for anarchy it has to be intended the absence of a supranational power, form of government, which regulates the states at the international system level and has the power to compel them to conform to international law. In the international arena, states are seen as sovereign centred-units and the major threat that they face is war. ${ }^{12}$

Although neorealists recognise that war is not the only threat, in the field of security studies they consider it being "the" threat, to avoid a dispersion of the meaning of security.

Thus, to recall Wolfers' statement quoted in the introduction to this essay, the objective dimension of international security is considered in military terms, as inter-states war, while the state's main preoccupation, or national interest, is read in terms of national security, which in this case is the safeguard of its territory and population. However, neorealists take also into account the subjective dimension, which is represented by the security dilemma. "Uncertainty is unavoidable when assessing intentions, which simply means that states can never be sure that other states do not have offensive intentions to go with their offensive military capability."13

12 Ibid.

${ }^{13}$ Mearsheimer, "False Promise of International Institutions", p. 10 
Consequently, because states cannot trust each other, they play a power-game whereas power is intended mainly in military terms and use the principle of deterrence, which during the Cold War was nuclear deterrence between the two super powers, to create a "secure" international environment. In reality, the international arena cannot become secure because, given the static and reproductive essence of anarchy, the threat of war is permanent. However, at the subjective level, the recognition of a state's military power by other states will render attacks more difficult because of the costs involved in war in general, and especially in nuclear war.

Thus, in terms of governance, a secondary role played by the states, which in the neorealist position are to be considered as political-territorial units, is simply not conceivable. Although it is given the opportunity for international cooperation, ultimately state will not renounce to their sovereignty with the end to create a supranational form of government. In fact, not only states are the only bodies legitimised at defining and implementing policies according to their national interests ${ }^{14}$ but also international institutions have to be considered as the reflection of self-interested calculations based on the distribution of power. ${ }^{15}$

The problem with this approach is that the state is seen as a unit and that it does not investigate how domestic policies influence national interests, which however, are seen narrowly in terms of national security threatened by inter-states war. Moreover, taking into account only states as main players in the international arena, neorealism does overlook the role of international actors other than states, which, although do not substitute the state, cannot merely be left out of the analysis because of their distinguishing characteristics.

With this, I refer, for example, to Krasner's position on international regimes ${ }^{16}$ While, in fact these regimes are initially established by states, usually to pursue determinate national interests, once they are active in the international system, because of their

${ }^{14} \mathrm{~K}$. Waltz, Emerging Structure of International Politics.

${ }^{15}$ Mearsheimer, "False Promise of International Institutions", p. 23.

${ }^{16}$ Stephen Krasner, "Regimes and the Limits of Realism: Regimes as Autonomous Variables", International Organisation 36 (2) 1982 
durability, which is considerably longer if compared to the years that a government stays in power, and especially because of the costs involved in case of dismantlement, not only they become more independent from state power, but also in some cases they can influence power dynamics within the state. For example, if we consider the IMF, during the negotiation with a borrowing country, the regime can alter the power of actors internal to the state, undermining for example the position of those groups opposed to its approach. ${ }^{17}$ Even more evident is the example of the European Union and of how the accession process can produce domestic changes once the process is in place: between 2000 and 2004 Turkey passed major reform packages to comply with the political requisites for opening the negotiations for accession; among these reforms there were some which affected founding principles of the Turkish State, starting from the rights guaranteed to minorities - Kurdish, especially - other than the only three recognised as such in the 1923 Treaty of Lausanne to rights like freedom of expression, for example with regard to court cases concerning political satire etcetera. According to the European Commission and Council official documents released at the end of $2004,{ }^{18}$ the accession process could take up to 15 years to be completed and considering the diverse opinions among the EU member states and within Turkey itself, its entry into the "club" is all but certain. Yet, some of these changes could prove irreversible.

Of course, a neorealist counter argument would be that in the field of security this does not happen. Yet, this is dependent on the meaning that we give to the concept of security; i.e. if we move away from its territorial-militaristic conception and consider economic, environmental and societal issues in terms of security. Indeed, such issues came to the surface after the end of the Cold War, in parallel with the debate on globalisation. To this regard, it is important to highlight how the neorealists deny both the novelty and degree of such phenomenon. Both Waltz and Hirst for example sustain that if for globalisation we refer to a process of continuous growth of trade and investments, in which countries are linked by intense exchanges in an interconnected world trading system, it has to be noted that

${ }^{17}$ Ibid. , p. 507.

${ }^{18}$ See: European Commission, 2004 Regular Report on Turkey's progress towards accession, Brussels, 5 November 2004 and Brussels European Council, Presidency Conclusions, 16-17 December 2004. 
2006] HOW DOES TRANSNATIONAL ISLAMIST TERRORISM

CHALLENGE THE CONCEPTIONS OF INTERNATIONAL SECURITY?

since the 1870 s there have been at least three major phases which meet these criteria. ${ }^{19}$ Furthermore, globalisation cannot even be intended simply as integration, because integration at the international level would presuppose a government with the legitimacy to direct and control policies of integration ${ }^{20}$; instead governments are only in a relation of interdependence, which is not even reciprocal, given disproportionate distribution of capabilities and growing level of inequalities. ${ }^{21}$

On the contrary, the globalist discourse takes into account the concept of globalisation, either in critical or positive way; and from it tries to develop a new concept of security.

\section{The globalist positions}

Although a conception of security other than the neorealist national/territorial security started to emerge in the $1980 \mathrm{~s}$, it is with the end of the Cold War that the academic debate was reinvigorated by new studies. In the 1980s, and specifically in 1982, the Palme Commission released a report in which presented the concept of "common" security. The Commission's work was primarily related to the proliferation of nuclear weapons and supported the need of international cooperation to create security among states, rather than from other states, on the ground that all states share the same security needs and face common threats. Yet, it also put forward the idea that security could not be conceived only in military terms, but that military power could only provide the means to achieve the end of the political and economic security of individuals. ${ }^{22}$

Consequently, the Palme Report had, I believe, two important implications: the first was on a structure-level and moved from the realist vision of a system in which states act independently to a system were states need to cooperate, thus moving away from the

${ }^{19} \mathrm{~K}$. Waltz, Globalization and Governance; P. Hirst, "The Global EconomyMyths and Reality", pp.410-411.

${ }^{20} \mathrm{~K}$. Waltz, Globalization and Governance, p. 697.

${ }^{21}$ Ibid. , pp. 699-670.

${ }^{22}$ Rothschild, "What is Security". 
lack of "trust" issue, which in the neorealist perspective is a source of insecurity. Secondly, it opened the way to a redefinition of the concept of security in relation to its ultimate referent, the State versus the individual.

Moreover, with the beginning of the 1990s, the necessity to rethink the conception of security was reinforced by two other types of considerations. On one hand, the observation of a decrease in interstates war consequent to the increased costs involved in state warfare, if compared to issues like overpopulation, risk of economic collapse, political oppression and crime (just to cite few), not only puts in shadow the realist argument, but also points to the state as a primary source of insecurity for its own population. ${ }^{23}$

On the other hand, the redefinition of the concept of security also responded to changes in political interests, for example in terms of contestation of existing policies: a redefinition of security forces after the end of the Cold War had to follow a redefinition of the concept of security. But also to influence the distribution of money and power both at the national and the international level: redefining security in economic rather than military terms affects the allocation of economic funding within governments' budget, not to mention the interests of global civil society organisations in promoting new conceptions of security in international fora. ${ }^{24}$

In this context, thinkers like Rothschild and Booth proposed a new set of analyses which present security as an "extended" concept. ${ }^{25}$ Specifically, it is extended horizontally for what concerns the type of security (political, economic, environmental), in all directions for what concerns the political responsibility of assuring security ${ }^{26}$; but ultimately it sees the human being as the final referent, a sort of human security. ${ }^{27}$ Specifically, the unfreezing of international politics, resulted from the end of the military confrontation characteristic of the Cold War, allowed for a

${ }^{23}$ Booth, Security and Emancipation.

${ }^{24}$ Rothschild, "What is Security".

${ }^{25}$ Ibid.

${ }^{26} \mathrm{Ibid}$.

${ }^{27}$ Ibid. ; Booth, Security and Emancipation. 
redefinition of the 'concept of security which draws on the liberal tradition, looks at the individual as main referent and at its well being as final end. ${ }^{28}$ In this sense, therefore, security is seen as emancipation and is linked to the idea of justice or social justice. ${ }^{29}$

But the redefinition of the concept of security should not be read only with regard to the geopolitical changes following the end of the Cold War. The necessity for a new understanding of the concept is also the result of the inherently globalising character of modernity,,$^{30}$ or to better say of what Beck calls a second modernity, to distinguish it from the initial stage of the process which is the modern development of the nation-state and to intend international security in terms of global risks rather than enemies ${ }^{31}$.

Thus, in terms of governance this interconnectedness calls for a rethinking of the international system, moving from the national level towards solutions that take into account the loss of capabilities for central governments to deal with global problems and favour new processes that can be understood either in terms of risks communities - communities that share the same risks and therefore deal with them at such level, ${ }^{32}$ till the, in my pinion, utopian idea of a cosmopolitan democracy, concept based on the assumption that political problems like security are only "partially addressable [even] by intergovernmental organizations. 33 "

The problem with this kind of approach, however, is twodimensional. On one hand it does extend the concept of security so far as to result in a dispersion of its meaning; issue that is also recognised by its proponents. ${ }^{34}$ Moreover, it has the disadvantage of

${ }^{28}$ Rothschild, "What is Security".

${ }^{29}$ Booth, Security and Emancipation, p. 319; Rothschild, "What is Security". ${ }^{30}$ Anthony Giddens, "The Globalizing of Modernity", Held D. and McGrew A. (eds) The Global Transformation Reader, Cambridge: Polity Press 1995 , p. 60.

${ }^{31}$ Ulrich Beck., World Risk Society, Cambridge: Polity Press 1999, pp. 1-3

${ }^{32}$ Ibid.

${ }^{33}$ Held, "Democracy and New International Order," Held D. and McGrew A

(eds) The Global Transformation Reader, Cambridge: Polity Press, 1995, p. 156.

${ }^{34}$ Rothschild, "What is Security". 
lacking of a commonly accepted conceptual structure to explain the international system, which can be capitalism, global market or world society according to the specific approach within the globalist position. ${ }^{35}$

On the other hand it presents, I believe, the contradiction of overlooking the role of the state, dismissing its capacity to deal with global problems, but at the same time it proposes solutions that really strengthen its role. In my opinion, in fact, it calls for a prominent role of international organisations, till the idea of cosmopolitan democracy; but it does so applying to the international arena the same principles that rule the modern state - like for example reforming the $\mathrm{UN}$ in a way that gives representation to the world citizens instead of their governments ${ }^{36}$ - that result difficult to be implemented successfully at the global level. In this, therefore, there is a congruence between globalist and neorealist positions because both develop their theories on the international system putting at the centre of their analysis - without questioning its nature - the state, intended as modern state, which is strengthened in its role or in its principles.

In contrast, one of the advantages of Regional Complex Security Theory is that, as well as trying to combine the two approaches above presented, it questions what has to be intended as state and how this affects the conception of national and thus international security.

\section{Regional Security Complex Theory (RSCT)}

Contrary to neorealism, RSCT looks at a concept of security which is wider and includes societal security, political security, environmental security etc. Yet, this extended concept is still analysed taking into account the importance of state sovereignty and territoriality and downplaying the security of the individual in favour of collective security. Furthermore, from the neorealist model it

${ }^{35}$ Buzan and Waever, Regions and Powers, The Structure of International Security, p. 29.

${ }^{36}$ D. Archibugi, "From the United Nations to Cosmopolitan Democracy", D. Archibugi and D. Held (eds.) Cosmopolitan Democracy, Cambridge: Polity Press, 1995, p. 135. 
2006] HOW DOES TRANSNATIONAL ISLAMIST TERRORISM

borrows the anarchic structure of the international system, with the difference that anarchy is not seen as a source of insecurity but simply as the context in which relations between state and non-state actors take place, at the international level. While, in fact, for the neorealist is the anarchic structure of the system which creates an insecure environment for states, as explained below in RSCT insecurity derives by the type of relation between actors, relation that can regard two different security referents simultaneously.

Far from explaining in detail a theory that has been developed throughout the last decade, it will suffice to highlight its main points. Firstly, at its basis there is the conception of security as "security....about the fate of human collectivities, and...secondarily about the personal security of individual human beings. ${ }^{37}$ This serves as a first way to narrow a concept that otherwise would include too many aspects, and also to distinguish the idea of security from "the everyday uncertainties of life. ${ }^{38}$

Secondly, the concept of territoriality cannot be downplayed in favour of the global level because "the normal rule underpinning the territorialisation of security relations [is] that most threats travel more easily over short distances than over long ones. ${ }^{39}$ " Territorialisation, however, is not intended only at state level, but at the regional one, although other levels (local, global and interregional) can play a role and ultimately even undermine the foundation of the theory itself. If for example economic threats, which are less territorialised, outnumber military ones, or incrementally states gain enough power to render distances an irrelevant obstacle, the interplay between levels will favour an analysis at the global rather than regional level. ${ }^{40}$

Thirdly, when talking of security threat, it has to be intended a threat which puts at risk the same existence of what is threatened. Although the idea of existential threat derives from the traditiona military-political understanding of security, intended as survival,

${ }^{37}$ Buzan, People, States and Fear, p. 19.

${ }^{38}$ Ibid.

${ }^{39}$ Buzan and Waever, Regions and Powers, The Structure of International Security, p. 12.

${ }^{40}$ Ibid. 
what is different here is the fact that what is existentially threatened is not only the sovereignty of a state, but it changes according to five different sectors of analysis: military, political, economic, environmental and societal. So, if for example we are in the field of social security, what will be put at risk of survival is the identity of a collectivity. ${ }^{41}$

Moreover, always for what concerns a delineation of the concept of security, it is necessary to remember that security is not an objective concept but the securitisation of a problem is an "intersubjective and socially constructed ${ }^{42}$ " process. Intersubjective because in a first instance, what is relevant is not necessarily the objective existence of a threat but the conditions under which an actor securitises that threat, or perceived threat, as existential threat; socially constructed because the perceived threat is not considered at the individual but at the social-collective level. ${ }^{43}$ Furthermore, the fact that a security threat is not necessarily another actor/state implies that the security relationship between two actors can concern two (or more) different threats, it is asymmetrical. For example, if in the Middle East we consider the relations between Syria and Turkey, for many years Syria has securitised Turkey's project to divert the Euphrates waters to serve its electricity needs - which also affects Iraq. This threat can be positioned in the environmental sector and also in the economic one as Syria's access to natural resources is vital to its economic development. Turkey, instead, has securitised Syria's support for Turkey's Kurdish minority, which can be analysed in terms of political security, which "is about the organizational stability of social order(s)." 44 In response the Kurdish, a non-state actor split between Syria, Turkey, Iran and Iraq, securitise their identity, which is "the organising concept in the societal sector ${ }^{45}$ " and so on.

${ }^{41}$ Barry Buzan, Ole Weaver and Jaap de Wilde, Security, a New Framework for Analysis, London: Lynne Rienner Publishers Inc., 1998, p. 21 ${ }^{42}$ Ibid., p.32.

${ }^{43}$ Buzan and Waever, Regions and Powers, The Structure of International Security, p. 71.

${ }^{44}$ Buzan et al., Security, a New Framework for Analysis, p. 141.

${ }^{45}$ Ibid. , p. 119. 
2006] HOW DOES TRANSNATIONAL ISLAMIST TERRORISM

Furthermore, the complexity of security dynamics is not evident only between sectors. Even in geographical terms, in fact, the actors just mentioned serve as example to identify how relations work on different levels simultaneously, where for example Turkey, which is comprehended in the Middle East, is also part of the European region with regard to its accession process, while Iran and Iraq because of their oil resources are "tied into the global economy. ${ }^{46 "}$

To recapitulate, this first section has served as an introduction to contextualise how the debate on international security has developed so far.

At one end of the spectrum we find the neorealist model, which looks at international security just considering a system analysis in which a prominent role is played by states, seen as geopolitical units which act in defence of their national security, intended as territorial security.

At the opposite end of the spectrum we find all those positions that either critical or in support of globalisation, start from this new phenomenon to redefine security in terms other than military/political and in many cases, drawing on the liberal tradition, look at the security of the individual rather than the state. The interconnectedness of a globalised world renders the role of the state more and more difficult in an international arena increasingly populated by international non-state actors.

Finally in the middle, Regional Security Complex Theory combines aspects of both models without dismissing the state and the principle of territoriality but considering security in terms closer to the globalist positions than the neorealist one. In the end what RSCT does is to expand the neorealist model and give a system structure to the globalist perspective.

So, how does Islamist terrorism fit into this debate? Does it confirm the validity of the neorealist approach? Can be analysed in terms of regional security?

${ }^{46}$ Buzan and Waever, Regions and Powers, The Structure of International Security, p. 197. 


\section{Global Islamist terrorism and international security}

As stated in the introduction, my argument is that Islamist terrorism challenges both the neorealist and the globalist perspectives, while it is better understood through the regionalist approach of Regional Security Complex Theory (RSCT), which results more adequate to grasp the complexity and multi-level consequences of this new phenomenon.

In this part, I analyse global Islamist terrorism in terms of international security (national security will be discussed in the following section), and through an overview of its historical development I highlight how it presents itself with a tridimensional character: national, transnational and global.

Specifically, I look at the three dimensions of Islamist terrorism as if they were stages of the same process, which do not necessarily follow a temporal logic and among which one aspect cannot be favoured at the expenses of the others, although it can look preponderant.

The way I have organised this part wants to highlight four temporal phases: the first which goes from the end of colonialism to the end of the 1960s provided the theoretical foundations for the development of Islamism as ideology. The 1970s signed the rise of militant Islam and an attempt of internationalisation of Islam; the third phase, the $1980 \mathrm{~s}$, is the stage of transnationalisation and finally from the 1990s onwards the phase of globalisation. I distinguish between transnational and global because with transnationalisation I refer to its networking organisation, as a result mainly of the Afghan war, whilst with the adjective global I refer to its global effects on the international system.

\section{The rise of political Islam and its transnational development}

Historically, Political Islam emerged at the beginning of the twentieth century in relation to the end of colonialism and the initial stage of national independence. In a political and social context 
2006] HOW DOES TRANSNATIONAL ISLAMIST TERRORISM

characterised by the presence of modern administrative structures and educated elites, legacy of the colonial powers, new movements started to emerge which promoted the idea that a political indigenous alternative to social tensions had to be researched within Islam itself. 47

Among such movements, one of the most renowned is the Muslim Brotherhood, which was founded in March 1928 as an "apolitical religious reform and mutual aid society" 48 - it became formally political only in 1941 when it announced its own candidates to the parliamentary elections - more focused on building mosques, schools and social infrastructures to legitimate Islam's social potentials in terms of development, than on the rejection of the status quo seen as the degeneration of pure Islam. In its first stage, in fact, Political Islam was more reformist than characterised by the radical positions expressed in the 1960 s by Sayyid Qutb, who with its writing Signposts signed the shift from reformist to radical thinking, providing the theoretical tools and ideology at the foundation of the Islamist movement of the $1970 \mathrm{~s} .{ }^{49}$

It is out of the reach of this paper to thoroughly analyse the many positions on the dynamics that produced this shift. Yet, I think it is important to highlight how while the first Brothers were trying to affirm a model of state rooted in Islamic ideology in opposition to a foreign (British) presence in the country and their inference in, control over Egyptian politics, in the 1960s the confrontation came from within the independent state, from a nationalist regime that had initially used the Brotherhood to reach its extensive and solid popular base but that tried to crush it soon after it acquired enough contro over the territory. Thanks to its three-tired membership structure, in fact, which was efficacious in solving the problem of varying degrees of commitment and beliefs among its members, 50 the Muslim Brotherhood had been able to gain such vast consensus in Egypt that

${ }^{47}$ Crockatt, America Embattled.

${ }^{48} \mathrm{Ziad}$ Munson, "Islamic Mobilization: Social Movement Theory and the Egyptian Muslim Brotherhood" The Sociological Quarterly 42(4), 2001, p. 488 .

${ }^{49}$ Gilles Kepel, The Roots of Radical Islam, London: Saqui, 2005.

${ }^{50}$ Munson, "Islamic Mobilization: Social Movement Theory and the Egyptian Muslim Brotherhood". 
when in 1953 Nasser, in an attempt to contrast all the voices discordant with his regime, decreed that all political parties would be dissolved, he exempted the movement because unable to face direct confrontation; although officially it was not a party but only an association. ${ }^{51}$ The right occasion, however, arrived in 1954, following the attempted assassination of Nasser: the Society was dissolved, many of its leaders killed and its members were either exiled or jailed in concentration camps. Indeed, the inhuman experience of the camps, in which many Brothers were forced to labours, proved critical for Qutb's radical analysis of a society that was now rejected as impure, not Muslim. ${ }^{52}$

This conflict between nationalist and Islamist ideologies however, was neither circumscribed to the 1960 s, nor to the Arab world. Mawlana Mawdudi, the founder of Jamaat-e-Islami, since the 1920s had clearly stated his opposition to a Muslim nationalism, especially if inspired by an European conception of the state, like the type that led to the birth of Pakistan in 1947, but advocated instead the idea of an Islamic republic extended to the whole India. Both Qutb and Mawdudi looked at Islam as a moral shelter for endangered Muslims, although the latter was more for an active participation in political institutions than for Qutb's radical break with the state without any space for compromise; but even if they could have thought of Islam as an instrument of social justice, they never explicitly theorised it in terms of social oppression as Khomeini did in the next decade. ${ }^{53}$

Indeed, in the 1970s the opportunity for the affirmation of Islamism, which culminated in the 1979 Iranian revolution seen by many as unifying symbol ${ }^{54}$, was facilitated by the political failure of both nationalist ideologies, which for example started to loose terrain after the 1967 defeat against Israel, and of reformist left movements like the Arab-Socialism. Moreover, these political aspects converged with economic and social factors like increasing levels of

${ }^{51} \mathrm{Kepel}$, Roots of Radical Islam, p. 23

${ }^{52}$ Ibid.

${ }^{53}$ Gilles Kepel, Jihad, The Trial of Political Islam, London: I.B. Tauris \& Co., 2006.

${ }^{54}$ Crockatt, America Embattled. 
2006] HOW DOES TRANSNATIONAL ISLAMIST TERRORISM

urbanisation and literacy, which enhanced a sense of frustration among those educated who could not fulfil their employment expectations. ${ }^{55}$ Islamist discourse, however, had to face a profound division between two groups of adepts: the poor young base and the bourgeoisie, the former aiming at a social-revolutionary state, the second at achieving access to power without drastically changing the existing hierarchies. Where the two could not be unified, the division transformed in internal conflict, like in Algeria where the confrontation resulted in civil war in 1992, or in Egypt where terroris attacks against tourists had the main objective of hitting the economic interests of the middle class. ${ }^{56}$

At the same time, Islam itself was undergoing a profound transformation. In fact, following the 1973 conflict between Syria and Saudi Arabia against Israel, and the oil crisis which gave the Gulf countries, especially Saudi Arabia, fast growing revenues and dominant economic power, the Wahhabite doctrine of the Arabian peninsula saw the opportunity to impose itself as dominant at the international level, at least among Sunni Muslims, and try to transform Islam in a unifying force. "The objective was to bring Islam to the forefront of the international scene, to substitute it for the various discredited nationalist movements, and to refine the multitude of voices within the religion down to the single creed of the masters of Mecca." ${ }^{57}$

While, in fact, prior to 1973 Islam was characterised by national or local traditions, the Saudis, taking advantage of being the land of the two holy places of Islam - Mecca and Medina - and of the wave of labour immigrants coming from all over the Muslim world because attracted by the oil revenues, achieved the objective of establishing "a transnational Saudi system [that] insinuated itself between state and society in the majority of the Muslim countries...".58

${ }^{55} \mathrm{Ibid}$.
${ }^{56} \mathrm{Kepel}$, Jihad, Trial of Political Islam.
${ }^{57} \mathrm{Ibid}$.


And this process of transnationalisation found its peak in the 1980s with the Afghan war, which linked Middle East politics to the wider context of the Cold War through the active role played in the conflict by the ex colonial powers and the US. While, in fact, identifying western powers' economic and geopolitical interests in the Middle East as the direct cause of Islamist terror can be misleading, their direct involvement in regional conflicts is considered critical by those who advocate the transnational character of terrorism.

Substantially, the Afghan war was transnational in two aspects: firstly it was characterised by the active participation of Saudi Arabia, Pakistan and the US, plus a number of other countries like Britain that played a secondary role. While the CIA provided weapons and specialist training in guerrilla warfare, and Saudi Arabia was in charge of financing the guerrillas, Pakistan secret services, the ISI, were responsible for the recruitment of the volunteers, for their supervision within training camps set in Pakistan and the coordination of the operations in Afghanistan. ${ }^{59}$

Secondly, and more important, voluntary fighters, hence called Arab- Afghans, were recruited throughout the whole Muslim world from the Far East to East Africa, up to 35,000 from 43 Islamic countries in the decade 1982-1992; and thousands more went to study in the madrassas on the borders between Pakistan and Afghanistan. "Eventually more than 100,000 Muslim radicals were to have direct contact with Pakistan and Afghanistan and be influenced by the jihad." 60 The active involvement of so many people and the successful outcome of the conflict, the defeat of the Soviets, reinforced a sense of unity and achievement among the volunteers; feeling that after the end of the war could be channelled onto new struggles. "The dispersion all over the world, after 1992, of the jihadist-salafists formerly concentrated in Kabul and Peshawar, more than anything else, explains the sudden, lightning expansion of radical Islamism in Muslim countries and the West."61 Indeed, it is

${ }^{59}$ Mahmood, Good Muslim, Bad Muslim, p.130.

${ }^{60}$ A. Rashid, Taliban: the Story of the Afghan Warlords, London: Pan Books, 2001.

${ }^{61} \mathrm{Kepel}$, Jihad, Trial of Political Islam, p. 299. 
general knowledge that key leaders of most of the major recent terrorist attacks, including bin Laden and his closest partners, were veterans of the war. ${ }^{62}$ In Afghanistan Bin Laden and Al-Zawahiri began to formulate the notion of global jihad and through international terrorist attacks in the years following the end of the conflict they tested it. ${ }^{63}$ From a western perspective, instead, the West/United States, too focused on the Soviet enemy, committed the strategic mistake of forging the fighters without foreseeing the "blowback"64 which would have resulted initially in the test-attacks to the American embassies in Kenya and Tanzania in 1998, to then find its peak in September 11, 2001, Madrid 2004, London 2005.

In this sense, the Afghan war represents the no-return point of the transformation of Islamist terrorism in a transnational actor, whose unifying principle is the idea of the ummah.

According to this reading of history, therefore, the transnationalisation of Islamist terrorism would enter the debate on international security from a globalist perspective. The deterritorialisation at the basis of this position would be evident in the universal value of the ummah as source of identity and in the networking organisation of the terrorist cells. Islamist terrorism becomes the violent expression of a whole of people that notwithstanding their country and nation of origins are unified in the rejection of exogenous values, ideologies and institutions, being this communism or the consumerism of the West. If we look at globalisation as a product of modernity, transnational Islamist terrorism is a reaction to modernity, or a "reactionary blowback" 65 , as well as a product of modernity/globalisation for its use of the media, of technology and also for its discourse techniques, for the instrumental use of concepts that appeal to the masses, like the Arab-

${ }^{62}$ Mahmood, Good Muslim, Bad Muslim, p. 139

${ }^{63} \mathrm{Kepel}$, The War for Muslim Minds: Islam and the West, Cambridge, Massachusetts and London: The Belknap Press of Harvard University Press, 2004, p. 71

${ }^{64}$ Crockatt, America Embattled, p. 107.

${ }^{65} \mathrm{R}$. Saull, "Reactionary blowback: the uneven ends of the Cold War and the origins of contemporary conflict in world politics", Colas A and Saull R. (eds) The War on Terrorism and the American 'Empire' after the Cold War, London and New York: Routledge, 2006. 
Israeli conflict, which is used more as a medium of recruitment than as political objective, as Al-Zawahiri himself clearly declares in his Knights under the Prophet's Banner, when he says that "the Muslim umma will only participate [in jihad] if the masses understand the jihadists' slogans clearly, and the slogan with the greatest mobilizing power [...is] the call to jihad against Israel." 66

In this context, there is deterritorialisation not only because terrorist groups cannot be linked to a state, and even if they are supported by a state this does not happen in an official way, but also because the national level dissolves in the international one. So, to use the terminology of the first chapter, issues of social injustice what Booth could refer to as social insecurity -which are born at the national level, within the state, were the motor to create an ideology which initially developed in relation to its opposition to the state, until it found in the Afghan war the opportunity to part from the national level to the transnational one and become a source of international insecurity, which in the case of terrorism is not just an abstract concept but is expressed in physical violence.

However, the problem of this approach is that it highlights the transnational level at the expenses of the national one, thus overlooking the role of the state. Such approach is, in fact, criticised by many who deny or better pose in shadow the transnational character of Islamist terrorism, privileging instead an analysis of the contingency of terrorist groups ${ }^{67}$ and of how the national level is still very much the centre of international politics.

\section{A neorealist counter-argument: the central role of the state}

While, in fact, the idea of transnationalisation is not denied for what concerns cultural and ideological trades among populations, it is also argued that this phenomenon is not new in a region whose populations have always maintained cross-border relations. Certainly, instead, the transnational aspect is put in discussion in the realm of International Relations, because of its implications for the role of the

${ }^{66}$ Kepel, War for Muslim Minds, p.102.

${ }^{67}$ Halliday, Two Hours that Shook the World, p. 58. 
2006] HOW DOES TRANSNATIONAL ISLAMIST TERRORISM

state in the international and domestic arena. ${ }^{68}$ In this sense, therefore, terrorist movements have to be analysed in relation to the local context in which they originate, especially the State Accordingly, even Al-Qaeda that for the advocates of transnational Islamist terrorism represents a "quintessentially transnational organisation" 69 has to be studied in relation to contingent aspects: its opposition to the Saudi Arabia regime's decision to allow the presence of US military troupes on holy land, its relations with the Afghan state ${ }^{70}$ or the fact that its hard core basis is formed by Sunni Muslims thus mirroring the profound divide between factions within Islam and consequently serving as a counter-argument to those who tend to overlook these partisanships in favour of a holistic vision of Islam.

The contingency of such movements is clear through history, in their opposition to state's intervention in education, family policy, to regime's corruption, and so on. ${ }^{71}$ Moreover, these groups are also analysed in terms of modernity or reaction to modernity at the national level both because the State is a product of modernity and because at the same time they draw on modern ideologies or discourses to support their actions and statements within a state context. An explicative example of this is the Iranian revolution, which was precipitated by modern issues like corruption, mass migration, originated in urban centres and was presented to the world through Khomeini's replication of modern radical politics. ${ }^{72}$ And the specificity of the revolution resides in the fact that it did not initiate other revolutions throughout the region or changed national boundaries in the name of Islam; neither with its calls to Iraqi Shias during the war with Iraq, nor in the following years. Instead, Iranian diplomacy has more and more developed in national terms, defending the national interests of the Iranian state, thus reinforcing the realist argument. $^{73}$

${ }^{68}$ Halliday, Middle East in International Relations, p. 232.

${ }^{69}$ Crockatt, America Embettled, p. 105.

${ }^{70}$ Halliday, Middle East in International Relations, p. 242.

${ }^{71}$ Ibid.

${ }^{72}$ Halliday, Two Hours that Shook the World, p. 203.

${ }^{73}$ Halliday, Middle East in International Relations , p. 243. 
"At least since the death of Ayatollah Khomeini in 1989, Iranian foreign policy has been shaped by Iranian national interests rather than by ideology: keeping a low profile regarding the Soviet presence in Afghanistan; support for Christian Armenia against a fellow Shia country (Azerbaijan)... and the instrumentalisation of Shia minorities abroad in the name of the Muslim ummah and then letting them down as soon as it suited...Tehran discreetly supported the US operation Enduring Freedom to topple the Taliban regime in October 2001 and did not oppose the occupation of Iraq in 2003."74

This approach does account for the existence of non-state actors within the international system, as does the neorealist approach; what it does deny is the existence of transnational actors. Transnationalisation, per se, is considered only in relation to supranational structures, which can include the financial system, rather than the balance of power of the information technology revolution, which are associated with the process of globalisation. ${ }^{75}$ These structures can shape the actors, state and non-state, within them in a mutual relationship of influence but finally the "whole process rests...on the underpinning, in terms of military security, rule of law and regulation, provided by states."76

Accordingly, this perspective enters the international security debate from neorealist view but even in this case there are several falls. Firstly, the threat to national security posed by terrorism is not in terms of inter-states war, although it is a physical threat to people, but not to another state's territory, or to better say to its sovereignty over a territory, because no terrorist group has invaded a country trying to replace or control its government. Second, the threat does not come from another state but from an enemy that is not defined by territorial boundaries or a determinate population, nor it has institutions with which to negotiate an eventual truce; and in this sense it can be said that it is a transnational actor. Indeed, although the core of Al Qaeda was sheltered in Afghanistan, which it used as a base to coordinate its operations, its "soldiers" have been in each case volunteers coming from all over the Muslim world, and more recently

${ }^{74}$ Roy, Globalised Islam, p. 62.

${ }^{75}$ Halliday, Middle East in International Relations, p. 259.

${ }^{76}$ Ibid. 
2006] HOW DOES TRANSNATIONAL ISLAMIST TERRORISM

from within the West - enough to think of the London bombings of July 2005. In this sense, in fact, "Al Qaeda [is] less a military base of operations than a database that connect[s] jihadists all over the world via the Internet."77

Now, a counter-argument could be that the neorealist perspective does explain part of the process: that is the unilateral behaviour of the United States and its allies, which, in the context of the war on terror, for example, decided to attack Iraq against the UN Security Council position, alleging Saddam Hussein's links to $\mathrm{Al}$ Qaeda. This would confirm the neorealist approach to international cooperation and especially to international institutions, showing how the anarchic structure of the international system renders international organisations, to which states adhere voluntarily, incapable of forcing a member to change its behaviour when acting in the name of national security, even more if this member is military and economically powerful and thus does not fear any sanctions.

Yet, I do not think that the international community in the past five years can be read only in terms of unilateral or multilateral defence of national security. Not only, in fact, has Islamist terrorism represented an opportunity for the US to take the lead of world politics, although with the declared aim of spreading democracy, as universal value, to create a secure environment in the Middle East and elsewhere ${ }^{78}$, but has also had repercussions on the international economy and on the domestic realm in terms of debates for more restrictive policies on immigration, citizenship and civil liberties. Without considering that the war on terror not only has not achieved its first objective of crushing the terrorist network, but also from defensive it has become a source of international insecurity itself, especially for the reaction within, but not only, the Muslim world to the current situation in Afghanistan, or to the invasion of Iraq, which, it is widely recognised, has resulted in a increase of volunteers recruited by terrorist cells; and a source of regional insecurity within the Middle East following the "replacement" of Saddam Hussein.

${ }^{77}$ Kepel, War of Muslim Minds, p.6.

${ }^{78}$ See The National Security Strategy of the United States of America, Spetember 2002 and March 2006. 
This intersection of level of analysis, therefore, calls for an approach that, although maintaining the principle of territoriality, is open to consideration of deterritorialisation.

\section{The third dimension of Islamist terrorism: the global level}

My position to this regard is that the transnational and contingent views of Islamist terrorism are not in contradiction but represent two dimensions of the same process, of which the third is its global character. While, in fact, the understanding of its causes has to be researched locally, this meaning either nationally or regionally, in the tension between state and society, and the recognition of its transnational character serves to understand its networking organisation, the third dimension refers to its unintentional effects at the global level, "where the global consequences of Al Qaeda's jihad have outstripped its local causes, and so have exceeded its intentions"79 thus resulting in a loss of control over the international system, not only for the terrorist networks but also for the other actors within it. If, for example, we compare today's terrorism to the Palestinian movement of the 1970 s, while excesses of the Palestinians "were finally legitimized within an order of intentionality dedicated to the establishment of a national state" 80 , not only the former cannot be included in this category, but also the attacks on September 11 have had unpredictable repercussions internationally. This is not to say that $\mathrm{Al}$ Qaeda has not concrete grievances - many times, jus to present one example, bin Laden has requested the withdrawal of US troupes from holy land - but its violence is not instrumental to a "constructive" end, thus rendering traditional concepts inadequate to deal with it ${ }^{81}$, or at least to deal with every aspect of it.

This multidimensionality, however, can be grasped through the Regional Security Complex Theory model that, as stated in the previous part, even starting from the principle of territoriality, extends the concept of security, which is however security of a collectivity rather than the individual, over the traditional idea of

${ }^{79}$ Faisal Devji, Landscapes of the Jihad, London: C. Hurst \& Co., 2005, p.2. ${ }^{80}$ Ibid., p.3.

${ }^{81}$ Ibid., p.161. 
2006] HOW DOES TRANSNATIONAL ISLAMIST TERRORISM

national security and over the state level; and for the way it is conceived is open to considering also the concept of deterritorialisation.

In this sense therefore, Islamic fundamentalism and its relation with the West/USA can be analysed simultaneously at different intersecting levels. On one hand, drawing on the theological and philosophical roots of radical Islam, one could look at fundamentalism as securitisation, in the sense that what is threatened is fundamentalism itself presented as true faith - an example to this regard could be the fact that Qutb included among those to oppose also Muslim societies and rulers whose purity of faith had been corrupted. ${ }^{82}$ The West, in this analysis, becomes the personification of military, economic, cultural threat and accordingly the conflict is played at the global level because "it is possible to aim violent action at any expression of the West without demanding any specific link to a particular cause."83 This argument, however, although seems close to the Clash of Civilizations position ${ }^{84}$, as it is likewise taken at the cultural and global levels, does not refer to the clash between Western and Islamic cultures or religions, which do not exist as unifying concepts, but to the discourses and practices of those on both sides who use their differences instrumentally. In fact, even if in reality there is no one Islam or Western culture, the fact that this universalism is declared and pursued makes it real in political terms.

On the other hand, drawing on bin Laden's statements, what is securitised is US military presence on holy land and US alliance to Israel: in this sense, therefore, the relation between $\mathrm{Al}$ Qaeda and the West/USA can be included in the Middle East Regional Security Complex. ${ }^{85}$; that is it calls for an analysis at the regional level.

The fact is that these two types of securitisations are not exclusive but cross each other: in ideological terms, the existential threat is positioned at the global level because, regarding the

${ }^{82}$ Buzan and Waever, Regions and Powers, p.206.

${ }^{83}$ Ibid., p. 207.

${ }^{84}$ Samuel Huntington, "The Clash of Civilizations?", Huntington S. (ed) The

Clash of Civilizations? The Debate, New York: Foreign Affairs, 1996.

${ }^{85}$ Buzan and Waever, Regions and Powers, p.208. 
theoretical foundation of Islamist terrorism, it does not need a state to be contextualised. In practical terms it is positioned at the regional level because concrete grievances, against US policies in the Middle East for example, are easier to be securitised to the eyes of a wider audience. However, as the regional securitisation is instrumental and "draws on a deeper layer of general securitisation" 86 , it is important to consider also the global level as in reality this specific regional securitisation could just be replaced by another type. In this context, the national level also intervenes, for example, in the role played by Afghanistan before $9 / 11$ as base used by terrorist groups to coordinate their operations; the national level in this sense is an "insulator." 87

Furthermore, the national level also contributes to create the global dimension of terrorism in relation to a transnational identity. Indeed, the fact that Islamist parties in the Muslim World have gone through a process of nationalisation, thus failing to create that international revolutionary wave of which initially the Iranian revolution had become a symbol or a promise - "in Palestine, Hamas and Islamic Jihad [had] challenged Arafat's Palestine Liberation organisation (PLO) not on points relating to Islam, but for 'betraying' the national interests of the Palestinian people" 88 - means that they have lost appeal beyond their national borders, thus making space for more radical positions which fill this vacuum offering, especially to Muslims living outside the region, the "comfort" idea of an imagined international community, the ummah, but which do not pursue the constructive project of building an Islamic state, as the first reformists did. In this sense, to distinguish it from previous movements, we can call this new Islamism "neofundamentalism - intending a "closed, scripturalist and conservative view of Islam that rejects the national and statist dimension in favour of the ummah...". 89

To sum up, therefore, Islamist terrorism, as expression of a form of neofundamentalism, can be better analysed in terms of international security adopting Regional Security Complex Theory,

${ }^{86}$ Ibid., p.209.

${ }^{87}$ Ibid., p. 210 .

${ }^{88}$ Roy, Globalised Islam, p.63.

${ }^{89}$ Ibid., p.1. 
2006] HOW DOES TRANSNATIONAL ISLAMIST TERRORISM

which combines aspects of neorealist and globalist perspectives and allows working on different levels of analysis simultaneously.

In this sense, we take in consideration the global level for what concerns the theoretical foundation of Islamism, which is constructed around the attempt to build universal concepts like the ummah and to dissolve regional and local differences. Moreover, the global dimension of Islamist terrorism refers to the unintentional effects that it has on the international system.

At the regional level, we analyse concrete grievances, like Al Qaeda's critique to US military presence on holy land, which serve to give the targeted audience a more real justification to determinate actions. As said, these levels intersect each other because they all are stages of the same process and because the regional level for example draws on the global.

The national level, instead, can have a less prominent role serving as insulator, if referring to Afghanistan used by terrorist groups as a base to coordinate their operations, or, as discussed in the next section, can become of critical importance in relation to a redefinition of the concept of national security.

\section{Global Islamist terrorism and national security}

In this final part I analyse how Islamic neofundamentalism, embodied by global terrorism, also contributes to redefine, or to better say to question, the concept of national security. Specifically, my analysis aims to show how the understanding of national security cannot be limited to the neorealist conception of territorial security, which is mainly defined in relation to the acceptance at the international level of the principle of sovereignty, but needs to be investigated primarily in relation to dynamics internal to the state, which are however influenced by external factors like globalisation that even though has not reached its full potentials is however a process in fieri, and the spread of radicalism at the global level.

Moreover, although my argument is founded on the acceptance of globalisation, it does not reflect the globalists' conception of security as emancipation but is manly based around the idea of how 
identity issues, especially with regard to the construction of an Islamist transnational identity outside the Islamic world - specifically in Europe - can become a matter of national security because they contest the very idea of the State, not just its capabilities at dealing with global problems.

It is out of the reach of this paper to engage in a debate on the theories of the State as a political entity; so below I briefly present the notion of state that I find more comprehensive, which I borrow from Buzan. ${ }^{90}$ Then, I explain how Islamist transnational identity becomes a national security issue in relation to this conception of the state.

\section{The identity of the State}

Departing from the Weberian definition of state, which distinguishes between society and state intended in bureaucratic terms as central government, and from the political-territorial view specific of International Relations ${ }^{91}$, state is here intended as a whole of three units: its physical base, which includes population and territory, its institutional expression, which refer to the institutions that govern and regulate it, and finally the idea of state, which is the idea of what the state represents for its people and institutions, which "establishes the legitimacy [of the state] in the minds of its people" and which is founded on the concept of nation and on organising ideologies where for nation is intended a large group of people who share the same culture and possibly ethnic background ${ }^{92}$ - as the principal source of identity for the state. In this sense, therefore, sovereignty becomes the criterion used to distinguish a state from other social units $^{93}$, but does not suffice in itself to define a state.

Accordingly, then, a threat to national security can be a threat to any of these units, and not only to its physical base, as for neorealism. This distinction, I believe, is important because in primis it supports the need to use a model of analysis which, although

${ }^{90}$ Buzan, People, States and Fear.

${ }^{91}$ Ibid., pp.59-60.

${ }^{92}$ Ibid., p.66,70.

${ }^{93}$ Ibid., p.67. 
maintaining the importance of territoriality, takes into account the complexity of security relations; complexity which is manifest not only in terms of external threats to the state (in a system in which the state is one of the actors) but also internally. Secondly, it presents a flexible model in which the dynamics between the three units can produce different variants of state, which is also a way to respond to the critique that states vary and that a uniform nation-state model, with which we refer when intending the modern state, "remains more aspiration for the future than present reality." 94

Specifically, according to this approach four different types of state can be identified: the nation-state like Italy or Japan in which the nation "provides the state with both a strong identity in the international arena, and a solid base of domestic legitimacy; the statenation in which the state "plays an instrumental role in creating the nation", characteristic of states where the population is a result of waves of migration like the United States or many countries in Latin America. In this case, citizens can retain a dual identity, deriving from their pristine culture and the state. In this type is also included a state like Great Britain where a new identity, British, is added on top of existing ones - Welsh, English, Scottish. The third type is the part nation-state where "a nation is divided up among two or more states and where the population of each state consists largely of people from that nation - a clear example of this category can be Germany during the Cold War; and finally the multination-state or states that "contain two or more substantially complete nations within their boundaries." 95 This last typology can in turn be divided in two subtypes: the federative state - which does not correspond only to a federative political structure - in which "separate nations are allowed...to pursue their own identities, and attempts are made to structure the state in such a way that no one nationality comes to dominate the whole structure."96 Examples are Canada and the ex Yugoslavia. And finally there is the imperial state sub-type, in which

${ }^{94} \mathrm{M}$. Mann, "Has Globalization ended the Rise and Rise of the NationState?", Held D. and McGrew A. (eds) The Global Transformation Reader, Cambridge: Polity Press, 2003.

${ }^{95}$ Buzan, People, States and Fear, pp.74,75.

${ }^{96}$ Ibid.,p.76. 
"one of the nations within the state dominates the state structures to its own advantage." 97

These different models reflect the fact that the relation between nation and state can be different and therefore that states can experience different type of national security. Once again, the neorealist perspective is put in discussion because not only national security cannot be limited to territorial security but there can be many national securities.

Moreover, to the concept of nation it has to be added the influence, as source of identity, of the ideologies that organise the institutional structure of the state. "These can take the form of identification with some fairly general principles, like Islam, or democracy, or some specific doctrine, like republicanism or communism." 98 Accordingly, ideologies that have or aspire to have a strong universal element will be seen in terms of threat to national security because intrinsically their universalism is opposed to the idea of a nation-state. And, as shown below, this is exactly the threat of Islamist transnational identity, which I think could prove more difficult to deal with especially in Europe where the states resemble either the nation-state model or the variant of the state-nation as embodied by Britain, but in any case states in which the dominant nations are deeply rooted in the territory.

\section{Islamist transnational identity as protest identity}

Within the debate on Islamist terrorism, identity issues are usually considered in cultural terms and related to the Clash of Civilisations argument. In this sense, a civilisation is seen as "the highest cultural grouping of people and the broadest level of cultural identity people have short of that which distinguishes humans from other species." 99 In this sphere, globalisation functions as an accelerator, which enhances the interactions between people of different civilisations, thus making them more conscious of their

${ }^{97}$ Ibid., p.76.

${ }^{98}$ Ibid., p.79.

${ }^{99}$ Huntington, Clash of Civilizations, p.3. 
2006] HOW DOES TRANSNATIONAL ISLAMIST TERRORISM

basic differences. Among these differences one of the most important is religion because this, more than ideologies and political regimes, shapes societies in terms of family, relations among sexes, hierarchies, etcetera. Moreover, through processes of economic modernisation and social change, globalisation also results in the polarisation of local identities towards a more general identity provided by the belonging to one civilisation. An example of this can be the increasing economic regionalism which - like in the case of the European Union or the Economic Cooperation Organisation - can be successful only when is pursued between countries which belong to a common civilisation and that in turn increases the "civilisationconsciousness."100

The problems with this approach, however, are that firstly it confounds religion and culture. While, in fact, a religion can be common to more cultures and there can be correlations between a certain religion and determinate social practices - like "the relationship between Protestantism and capitalism"101, a religion cannot be simply assimilated to one culture.

Secondly, a culturalist approach usually tends to see a culture in terms of homogeneous values, putting in shadow differences and ideological conflicts. This is, however, misleading because even in the West, more than a western culture that converges on common values, we should talk of "consensus...about institutions"102, thus working on a political rather than cultural level. Moreover, the unifying identity provided by radical Islamism is more a project to be constructed than something that exists or existed in the past, as for example it does not try to bridge the difference between Sunni and Shia but draws on the Wahhabite doctrine that, as seen in the previous section, in the 1970 s searched for an international dominant role trying to play down differences within Islam. Its global appeal, in fact, "depends upon the erosion of traditional religious and political allegiances for its very existence."103

100 Ibid p 6

${ }^{101}$ Roy, Globalized Islam, p.11.

${ }^{102}$ Ibid, p. 13

${ }^{103}$ Devji, Landscapes of Jihad, p.25. 
My approach, therefore, starts from this argument that the construction of a unifying identity is a project in fieri and takes into account globalisation for its role not so much in raising the level of civilisations' awareness but in facilitating this process, with regard, for example, to its effects on migration and society. For what concerns migration, in fact, as well as the traditional type according to which a population would move permanently from one country to another, there is a new form of mobility of people, usually educated, who move across different countries and who do not necessarily "settle within the protective framework of a solidarity-group"104, thus loosening their ties to their original culture as opposed to the traditional diasporas and initiating a process of deculturation of pristine cultures. ${ }^{105}$

This of course does not happen only for Muslims; drawing on my personal experience: I am Italian, I have lived in the UK for four years, previously I had lived in Spain, I am taking a postgraduate degree, which in my curriculum vitae will be added to another postgraduate course attended in Italy. I am not planning to stay in the UK for much longer than few years but I am not planning to go back home either. I do have contacts in Italy; I read the major national newspapers websites on a daily basis but, although I visit home few times in a year, when I go back I do not feel part of that reality as strongly as before. At the same time, because I am not planning to stay in this country permanently, although influenced by my interaction with other people I am not trying to integrate as if I had come here to stay; I could say that I am trying to integrate at a social level but not at a political one as I feel more concern for the dynamics of Italian politics than for the English ones although concretely my daily life is affected and determined more by the latter rather than the former. My culture is changing because influenced by other cultures, not by the cultural changes that my Italian friends are experiencing at home. In few years time, when I move to another country, my being Italian will not mirror what being Italian will be. On a larger scale, thus, this could contribute to create a deterritorialised and deculturalised "Italianism".

${ }^{104}$ Roy, Globalized Islam, p. 118

${ }^{105}$ Ibid. 
2006] HOW DOES TRANSNATIONAL ISLAMIST TERRORISM

At the same time, this process of deculturation of pristine cultures is in act even in traditional type of immigration: solidaritygroup ties tend to fade away among second and third-generation migrants, who have received a Western-type education and often do not speak the language of origin of their parents. Language, in fact, is an important source of collective identity and one of the starting points to construct a new one. So for example, if the British-born citizens of Pakistani background who in 2002 travelled to Pakistan to join radical groups like Jayash-e-Muhammad or Hizbage ut-Tahir during their trial spoke only English, in France there is a vivid debate on teaching Arabic in secondary schools; a language that does not pertain to many of the ethnic minority groups present on the territory and that is not intended to preserve pristine identities but to construct a new distinctive collective identity. ${ }^{106}$

The need to construct a new identity, however, is quite common among migrants not only because as we said, across generations original specificities tend to dissolve, but also because the host country tends to shape immigrants identity not so much through policies of assimilation or multiculturalism aimed at integration but through the establishment of new "identity patterns" 107 which do not mirror the ethnicities of origin. This usually happens through the construction of neo-ethnicities, in which culture and religion are confounded and become interchangeable; that is new ethnic groups are constructed for which the pristine culture is not relevant and religion, instead that in terms of spirituality, is seen as a source of homogeneous cultural patterns. ${ }^{108}$

Indeed, it is this phenomenon of search for, construction of a new identity that provides the opportunity for Islamic radicalism to find an international support base, especially among second and thirdgeneration Muslim migrants in the West. And it succeeds because it also finds fertile ground within spaces of social exclusion, populated by high rates of unemployment, created by immigration "on the margins of society in inner cities or suburbs." 109 In this sense,

${ }^{106}$ Ibid., pp.118-120

${ }^{107}$ Ibid., p. 102 .

${ }^{108}$ Ibid., p. 124

${ }^{109}$ Ibid., p. 143 
therefore, integration problems as well as frustrated economic and social expectations become a problem of security.

It would be erroneous, however, to think that the spread of radicalism owes its successful outcome only to a depressed social and economic context. An important role, in fact, is played by the research of an alternative identity that is used as protest ${ }^{110}$ by young people against both the host country and previous generations, so that this work of imagination, in the sense of an imagined ummah, becomes a "space of contestation."111

In this context, then, neofundamentalism has the advantage of providing an identity that fulfils that need for differentiation proper of contestation. In fact, it offers a new identity that is transnational not only because it is not linked to a specific territory but also because is disconnected from any specific culture. In this sense, therefore, the prefix trans, more than referring to a movement across space assumes the figurative meaning that it has in Latin, the idea of a movement across a form/dimension.

This focus on self rather than collective identity, however, is more a product of modernity typical of western societies than a derivation of traditions contingent for example to the Middle East; reason why we could say that "the time a space of modern Islamic radicalism is emancipated from the Middle East. It is a global space."112

On the other hand, because it "acknowledges without nostalgia the loss if pristine cultures, and sees as positive the opportunity to build a universal religious identity", neofundamentalism becomes also an agent of globalisation. ${ }^{113}$ In fact, it contributes to the deterritorialisation and deculturation of specific cultures, establishing homogeneous patterns of conduct which are aimed at unifying its very diverse base of adepts. ${ }^{114}$ And, interestingly enough, in the last

${ }^{110}$ Ibid.; Kepel, Jihad, The Trial of Political Islam.

${ }^{111}$ Appadurai, Modernity at Large, p.4.

${ }^{112}$ Roy, Globalized Islam, p.13.

${ }^{113}$ Ibid., p. 13.

${ }^{114}$ Ibid., p. 25 . 
2006] HOW DOES TRANSNATIONAL ISLAMIST TERRORISM

decade it has been exporting this process from West to East, in the sense that "more and more Islamic radicalism in Muslim countries has been organised in and from the West."115

Hence, to return to the relation between Islamist neofundamentalism and security, once again the analysis has to be approached at different levels simultaneously. Firstly, at the national level issues of social justice and integration are linked to identity issues, which also pertain to the global level in the idea of an imagined community. Then, the national and regional level - identity issues within a state and spread of radicalism in Europe - contribute to widen the global level, providing fertile terrain and support for the new universal identity. The global level, however, already finds a theoretical basis in the historical development of another region, the Middle East, within the context of the tension between state and society experienced in specific countries in that region, thus taking the analysis back to the national level.

Furthermore, the construction of an identity that is not linked to any specific culture or territory but that aims to become universally accepted in its rejection of any national and statist dimension is as much a problem of national security as it can be the threat of interstates war, if for national security we intend the preservation of the identity of the state. Problem of national security that has also repercussions in terms of international security or security of the international system as it questions the very idea of the state in a system formed predominantly by states.

And, if a state-centric approach is inadequate to highlight the multiple interconnections between levels and thus to control the effects of this phenomenon, so a globalist position seems as much inadequate because, taking notice of the inability of the state to deal with global problems, it proposes to pass political responsibility to international organisations. Yet, apart from the fact that currently international organisations have a legitimacy-issue in terms of representation and monopoly of coercion, even with regard to the objective of reforming them to establish a sort of cosmopolitan democracy my critique is that this idea looks more like a transposition

${ }^{115}$ Ibid., p.309. 
of the same principles that have so far constituted the modern state, in line with the Western philosophical tradition, than a new framework of analysis which wants to account for transformation and is based on a critical approach to the idea behind the state. Moving, in fact, from the national to the international level because states cannot deal with global problems seems to me similar to a way to escape the state of nature of an unregulated international system. But "something more than a simple desire to escape the state of nature is at work in the creation and maintenance of particular states. Otherwise there would be no barrier to the founding of a universal state which would solve the state of nature problem without causing the troublesome intermediary of a fragmented international system of sovereign states."116

To conclude, therefore, in this final part, I have approached the relation between radical Islamism, which is the theoretical foundation of Islamist terrorism, and national security, trying to show how as well as for international security the two mainstream positions, which privilege either a state-centric or a global approach to the concept, are inadequate to capture the complexity of this new phenomenon. Complexity that is evident not only in the intersection of "territorial" levels of analysis but also in the connection between national security and the transnational non-state identity advocated by Islamist neofundamentalism.

Personally, I think that within the process of evolution of the state, the threat embodied by the alternative of a transnational identity should involve some thought on the redefinition of what so far have been the traditional sources of political identity - where for political I refer to the Greek root of the word, meaning "of the polis", that in this case means "of the state" - especially in the perspective of a continuous incremental diversification of societies.

\section{Conclusions}

The purpose of this paper was to investigate how global Islamist terrorism challenges the mainstream conceptions of

${ }^{116}$ Buzan, People, States and Fear, p. 70, (Emphasis added.) 
2006] HOW DOES TRANSNATIONAL ISLAMIST TERRORISM

international security: the neorealist one that is formulated around the notion of an insecure international system, which reflects the state of nature for its anarchic structure and in which states enact balance of power and deterrence policies in defence of their national security, where national security has to be intended in territorial terms.

At the other end of the spectrum, instead, there are those positions that found their analysis on the growing interconnectedness of the international system due to the process of globalisation and to the presence of global problems which cannot be dealt with anymore at the state level. In this perspective, security is more security of the individual than of the state, which in fact is itself a source of threat for its populations and whose international role should be rebalanced in favour of an international form of governance.

The choice to put at the centre of my analysis global Islamist terrorism derives not by cultural bias but by the evident threat that it represents in terms of indiscriminate violence, by global elements that characterise it like the unintentional effects that it has on the international system and by the aspiration to universalism of the antistate ideology that it embodies.

Accordingly, in terms of international security, drawing on Regional Security Complex Theory, I have argued how the understanding of the complex dynamics between causes, means of organisation and effects of Islamist terrorism requires a conception of security more extended than the narrow neorealist definition, but that should still be intended in terms of collective rather than individual security and that should take in account both the principle of territoriality and the state level.

Finally, I have argued how also at the national level, the transnational identity based on the ummah as imagined community constructed by Islamist neofundamentalism challenges the theoretical models positioned at both ends of the spectrum, introducing an understanding of national security seen in terms of identity of the state and thus calling, within the context of an increasingly diversified society, for a rethinking of the idea of the state. 